\title{
EFFECT OF EXERCISE BENCH PRESS AND SITTING CALF WITH CHEST PRESS AND LEG PRESS TO POWERARM MUSCLE AND POWER LIMB MUSCLES
}

\author{
Choirul Umam*, Oce Wiriawan**, Edy Mintarto, \\ Universitas Negeri Surabaya* \\ Universitas Negeri Surabaya** \\ Universitas Negeri Surabaya*** \\ umam_renang@yahoo.com*
}

\begin{abstract}
Abstrack
This research aims to examine:1) How big the effectofbench press and sitting calf exercises to arm muscle power and leg muscle power; 2) How big the effect of chest press and leg press exercises to arm muscle power and leg muscle power; 3)How big the effect difference between bench press and sitting calf exercises and chest press and leg press exercises to to arm muscle power and leg muscle power. Research subject was boy student of SMA Negeri 1 Manyar as many 36 students, with age span 15-17 years which divided to three groups. Experiment group I received bench press and sitting calf while the second ones received chest press and leg press and the third experiment group performed activities according to daily routines. This type of research was applied quantitative research with quasi experimental research methods. The research design applied nonrandomized control group pretest-postest design. And data analysis used were $t$ test and MANOVA. The data collecting process was using a medicine ball to obtain arm muscle power data and jump DF for leg muscle power during pretest and posttest. The results showed the difference between the pretest and posttest means of each group, namely: experimental group I for arm muscle power $=28.3$ leg muscle power $=51.1$. The second experiment group for arm muscle power $=45.9$, leg muscle power $=78.2$. Experiment Group III for arm muscle power $=13.3$, leg muscle power $=27.1$. Based on the above analysis, it can be concluded that there was an increase in all dependent variables for each experimental group after received bench press and sitting calf, chest press and leg press exercises, whereas chest press and leg press exercises were more effective at increasing arm muscle power and leg muscle strength
\end{abstract}

Keywords: Weight training, Bench Press, Calf Sitting, Chest Pres, Leg Press, Arm Muscles Power, Leg Muscle Power.

Sportis an activity that is frequentlydone by humans, the sport itself is divided into two certainlycan not be separated by the so-called exercise. To achieve the maximum achievement should be through systematic training, continuous and 
obey the principles of practice which comprised using a scientific approach, so that the objectives of the exercise can be fulfilled. The outline of the exercise'sgoals and objectives, as follow, are to (a) improve overall basic and general physical qualities, (b) develop and enhance specific physical potentials, (c) add and refine technical skills, (d) develop and refine strategies, techniques, and playing patterns, and (e) improving the quality and psychic ability of sportsmen in competing (Sukadiyanto and Muluk, 2011, p.8).

One ofbiomotor important element is strength (power), which is the ability of muscle to overcome the resistance in a certain period (Mylsidayu, 2014, p.156). Biomotor Power is one of important physical condition element for achievement attainment in sports. Although for other elements are also required but if not have a sufficient power,certainly achievement will not be maximized. Kenny et al. (2012, p 211) muscle power is the key to the success of all sports. Therefore biomotor power training is very necessary because all the dynamic sports require power. Arms muscles and leg muscles are large muscle groups so it is very suitable to be trained. One of the exercises that can be used to increase muscle power of the arm and leg muscles is through weight training.

In this research researchers tried to find out the form and type of training that most effective in improving the muscle power of arms and leg power. Weight training is necessary for all sports that require physical condition. Weight training is a systematic method of training where the load is only used as a tool to increase muscle contraction in order to achieve certain goals. In today's dynamic sports are competing to improve the performance of leg muscles by modifying the type of exercise or using machine tools as equipment in supporting the exercise. One of the exercises that can increase muscle power of the arms and leg muscles is weight training are as follows: to train arm muscles using sitting calf, chest press and others, and to train leg muscles can use leg press, shoulder press, leg extension, leg curl, squat and others.

Arms and leg muscles are large muscle groups so it is suitable to be trained using weight training so that the muscle groups can. Based on the above problems, researchers consider the biomotor power really needs to be trained to be able to perform maximum movement and qualified. so in this research the researcher wanted to examine the effect of bench press exercise and sitting calf exercise with chest press and leg press exercises to arm muscle power and leg muscle power. This research was conducted on students of Class XI IPS in SMA Negeri 1 Manyar Gresik as many as 36 students.

Sukadiyanto and Muluk (2011, p.5) training or exercise is the main tool in the daily practice process to improve the quality of the function of the human organs system, thereby facilitating the athlete in the improvement of its motion, synergize with the explanation Hasanah $(2013$, p.8) the systematic process of practicing or working, which is done repeatedly, with workload increasing regularly. Then Ambarukmi (2007, p.1) adds the essence of the exercise are: 1) 
systematic process to improve the performance of athletes in the form of: fitness, skill and energy capacity, 2) considering to education aspect, 3) using scientific approach.

The objectives of the exercise outlined by Sukadiyanto and Muluk (2011, p.8) are to (a) improve overall basic and general physical qualities, (b) develop and enhance specific physical potentials, (c) add and refine technical skill, (d) develop and refine strategies, tactics and play patterns, and (e) improve the quality and psychicalability of athletes in competing.

Sukadiyanto and Muluk (2011) describe the principles of practice as follows: The principles of readiness, individual principles, adaptation principles, overload principles, progressive principles, specific principles, variation principles, warming up and cooling down principles, long-term practice principles, not excessive principles, and systematic principles. It can be concluded that good exercise is a meaningful exercise that suitable to the principles of exercise to maximize physical performance.

Strength is one of the basic components of biomotor thatrequired in every sport, Sukadiyanto and Muluk (2011, p.90). While Wiarto (2015, p.171) strength is the ability of the muscles to perform useful contractions to generate tension against a resistance. Weight training or is a systematic exercise where the load is only used as a tool to increase muscle strength in order to achieve certain goals. Weight training is one of the most used exercises by sports trainers to foster and improve the athlete's physical condition (Solissa, 2014, p.43). Other expert states, Warner (2011, p. 526) weight training is an exercise program designed to increase muscle strength and endurance through a series of weight training that burdens the muscular system and leads to physiological development.

Bompa (2015, p.124) exercise component consisted of: (1) volume of exercise, (2) intensity of exercise, (3) repetition, (4) set, (5) density, (6) rhythm of practice, (7) recovery between sets. Furthermore, Sukadiyanto and Muluk (2011, p. 26) describes the components of the exercise that can determine the process of supercompensation, namely: intensity, volume, recovery, and interval. The arm is a structure of the human body including the upper limbs and consists of two parts, the upper and lower arms. In the application of muscle power is very important seen from the sportpoint of view. Leg muscle exercise aims to improve the ability of leg muscles in terms of sports activities and daily activities. The importance of leg muscles is exercised because the contribution to the sport is big.

\section{METHODOLOGY}

Based on the research problems in this research, this research uses quantitative approach with quasi experiment method. In the experimental research, the researcher will give a treatment, this treatment in the form of weight training that is bench press and sitting calf trainings and beside that it also given chest press and leg press treatments and then observe the effect toarm muscle power and leg 
muscle power. The research design that used in this research was nonrandomize control group pretest-postest design. This design using the control group and pretest-posttest (Maksum, 2012, p.100). To equate the ability of each experimental group, the technique used was ordinal pairing technique.

\section{Table 1. Research Design}

\begin{tabular}{|c|c|c|c|c|c|c|c|}
\hline \multirow[t]{3}{*}{$\sim$} & \multirow[b]{3}{*}{ 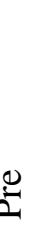 } & \multirow[b]{3}{*}{ ठิ } & $\begin{array}{l}\text { Experimental group } \\
1\end{array}$ & T11 & $\mathrm{X} 1$ & $\mathrm{~T} 21$ & \multirow[b]{3}{*}{2} \\
\hline & & & $\begin{array}{l}\text { Experimental group } \\
2\end{array}$ & T12 & $\mathrm{X} 2$ & $\mathrm{~T} 22$ & \\
\hline & & & Control group & $\mathrm{T} 23$ & - & $\mathrm{T} 23$ & \\
\hline
\end{tabular}

Research design (Maksum 2012)

Information:

S : Subject

Pre: Pretest

OP: Ordinal Pairing

T11: Experiment Group 1,

T21: Postest experimental group 1,

T12: Experiment Group 2,

T22: Postest experiment group 2,

T13: Control group without treatment

T23: Postest control group without treatment

$\mathrm{X} 1$ : Treatment exercises (bench press and sitting calf)

$\mathrm{X} 2$ : Treatment exercises (chest press and leg press)

-: No treatment (but received training according to thetraining given by the trainer)

PT: Post-test

Independent variables, including bench press and sitting calf exercises, and chest press and leg press exercises. While the dependent variable includes arms muscle power and leg muscle power. The population used in this researchwas all students of class XI IPS in SMA Negeri 1 Manyar Gresik as many as 36 students. This research is a population research because the entire population is sampled so that the population research is called 36 samples. For sample grouping this research using ordinal pairing technique, with objective that each group have same ability quality. Ordinal pairing is a way to classify a sample based on the resulting ranking when performing a pretest. Types of tests used to measure arm muscle power was using a $3 \mathrm{Kg}$ loadmedicine ball test. While for leg muscle power obtained from Jump DF results.

The data collected were analyzed descriptively and inferentially, to determine the category and to draw conclusions, in describing the results of the 
research used descriptive statistical calculations such as mean, standard deviation, variant, the lowest value and the highest value of the data collection. Then an inferential analysis technique wasconducted to retrieve and make a conclusion from the kinesthetic approach program effect by comparing two physical fitness mean values derived from pretest and posttest data. Both means will be compared using independent t-test. Prior to the independent t-test, normality test with Kolmogorov-smirnov and homogeneity test using Anova was performed. The level of significance used in this researchwas 0.05 for data processing using computer SPSS.

\section{Data Description}

\section{RESULTS}

The result of variable data in the experiment group I obtained significant arm muscle power improvement after Bench Press and Sitting Calftreatments, this wasobserved from the mean of arm muscle power when pretest as big as 442. and at during posttest that is 470.6 . The difference between posttest and pretest power of arm muscle mean was 28.3. If the increase in arm muscle power converted into percentage form then the percentage of arm muscle power increases by $6.0 \%$.

In addition, improvement also observed in leg muscle power, this can be seen from the mean of leg muscle power during pretest namely 994.9 while the mean leg muscle power on posttest was 1046.0. The difference between the posttest with pretest leg muscle power mean was 51.1. If the increase in arm muscle power converted into percentage form then the percentage increase in leg muscle power by $4.9 \%$.

The result of variable data in experiment group II was found that significant increase of arm muscle power after being given chest press treatment and leg press was seen from the mean of arm muscle power at pretest that is 457.6 and at posttest as big as 503.5.

\section{Figure1. Diagram of pretest and posttest results of experimental group I}

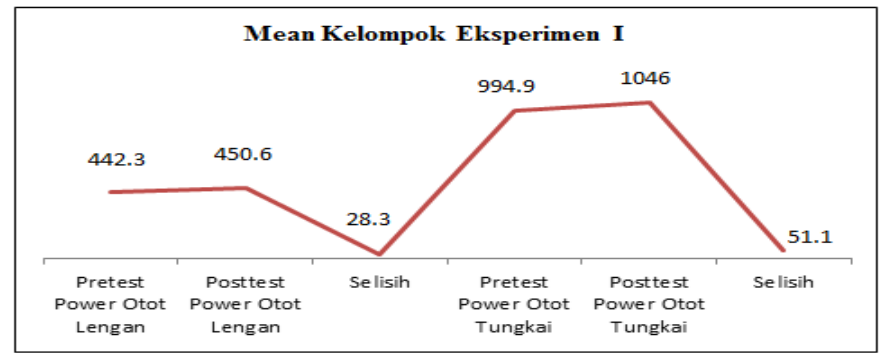

The difference between arm muscle power posttest andpretest mean was 45.9. If the increase in arm muscle power converted into percentage form then the percentage increase in arm muscle power is $9.1 \%$. 
In addition, the increase also occured in leg muscle power, this can be seen from the mean of leg muscle power at pretest that is 969.3 while the mean leg muscle power at $t$ posttest was 1047.4. The difference between the mean of posttest and pretest of leg muscle power as big as 78.2. If the increase in leg muscle power converted into percentage form then the percentage increase in leg muscle power by $7.5 \%$. For more details it will display the increased arms muscle power and leg muscle power in the experimental group II in the form of diagrams.

\section{Figure 2. Pretest and posttest result of experimental group II}

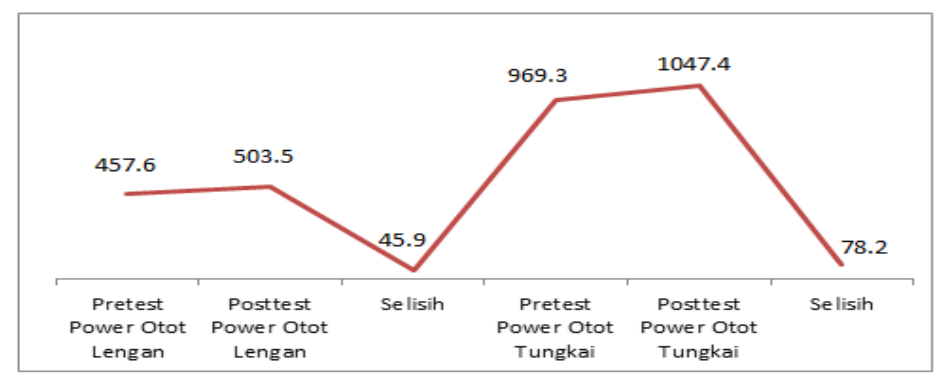

Theresult of variable data in control group obtained significant increase of arm muscle power during pretest that is 449.2 and at posttest namely 462.4. The difference between posttest andpretest arm muscle power mean was 13.3. If the increase in arm muscle power converted into percentage form then the percentage increase in arm muscle power by $2.9 \%$.

In addition, the increase also occured in leg muscle power, this can be seen from the mean of leg muscle power at pretest that is 996.7 , while the mean of leg muscle power at posttest that is 1023.8 . The difference between posttest and pretest mean was 27.1. If the increase in leg muscle power converted into percentage form then the percentage increase in arm muscle power by $2.6 \%$. For more details, it will displaythe increased of arm muscle power and leg muscle power in the control group in the form of bar charts.

Figure 3. Pretest and post-test results of the control group

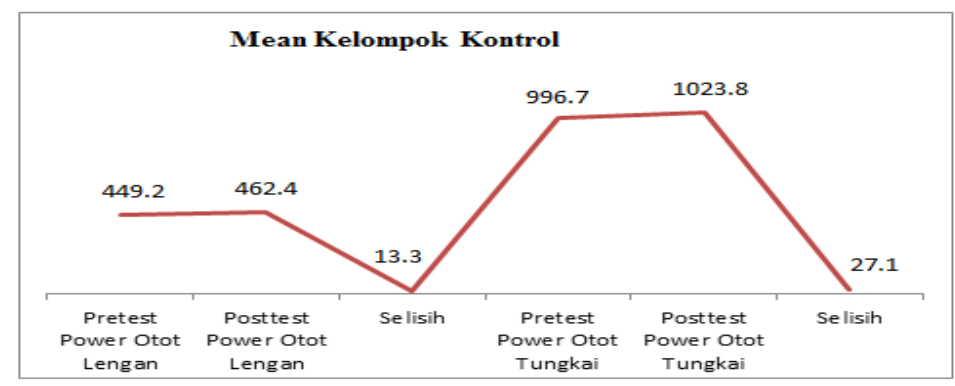

The data analysis consisted of Normality Test and Hypothesis Test, namely: 


\section{Normality Test}

The tested data was known that the data acquisition from two dependent variables namely arm muscle power and leg muscle power were normally distributed. This is because the significance or probability value of each group shows (p) or sig> 0.05 so that H0 is accepted. This means that data is drawn from normally distributed populations

\section{Table 2. Tests of Normality}

\begin{tabular}{|c|c|c|c|c|c|c|}
\hline \multirow{2}{*}{ Variabel } & \multirow{2}{*}{ Test } & $\begin{array}{c}\text { Kel. I } \\
\text { (BPSC) }\end{array}$ & $\begin{array}{c}\text { Kel. II } \\
\text { (CPLP) }\end{array}$ & $\begin{array}{c}\text { Kel. III } \\
\text { (KON) }\end{array}$ & \multirow{2}{*}{ Ket } & Status \\
\cline { 3 - 5 } & Sig & Sig & Sig & Normal \\
\hline $\begin{array}{c}\text { Power Otot } \\
\text { Lengan }\end{array}$ & Pretest & .587 & .479 & .864 & $\mathrm{P}>0.05$ & Normal \\
\cline { 2 - 6 } & Posttest & .996 & .343 & .989 & $\mathrm{P}>0.05$ & Normal \\
\hline $\begin{array}{c}\text { Power Otot } \\
\text { Tungkai }\end{array}$ & Pretest & 852 & .552 & .770 & $\mathrm{P}>0.05$ & Normal \\
\cline { 2 - 6 } & Posttest & .867 & .581 & .994 & $\mathrm{P}>0.05$ & Normal \\
\hline
\end{tabular}

\section{Homogeneity Test}

The data of the two dependent variables namelyarm muscle power and leg muscle power has homogeneous variance. This is because the significance value of each data is greater than the level of significance or $(p)>0.05$. So it can be stated that the variance in each group was the same or homogeneous.

\section{Table 3. Results of VarianceHomogeneity Test}

\begin{tabular}{|c|c|c|c|c|}
\hline Variabel & Test & Sig (P) & Ket & Status \\
\hline Kecepatan & Pre-test & .858 & $\mathrm{P}>0.05$ & Homogen \\
\cline { 2 - 5 } Shooting & Post-test & .758 & $\mathrm{P}>0.05$ & Homogen \\
\hline $\begin{array}{c}\text { Power Otot } \\
\text { Iungkai }\end{array}$ & Pre-test & .678 & $\mathrm{P}>0.05$ & Homogen \\
\cline { 2 - 5 } & Post-test & .879 & $\mathrm{P}>0.05$ & Homogen \\
\hline
\end{tabular}

The following will be presented the results of the Post Hoc test with LSD for arm muscle power variables.

\section{Table 4. Post-Hoc Test Results with LSD Variable Power Sleeve Muscles}

\begin{tabular}{|c|c|c|c|}
\hline \multicolumn{2}{|c|}{ Kelompok } & Mean difference & Signifikansi (p) \\
\hline \multirow{2}{*}{$\frac{\text { Eksperimen }}{\text { I }}$} & $\begin{array}{c}\text { Eksperimen } \\
\text { II }\end{array}$ & $-17.6667^{*}$ & 0,000 \\
\hline & Kontrol &,$- 15.0000^{*}$ & 0,001 \\
\hline \multirow{2}{*}{$\begin{array}{l}\text { Eksperimen } \\
\text { II }\end{array}$} & Eksperimen I & $17.6667^{*}$ & 0,000 \\
\hline & Kontrol & $32.6667^{*}$ & 0,000 \\
\hline \multirow[b]{2}{*}{ Kontrol } & Eksperimen I & $-15.0000^{*}$ & 0,001 \\
\hline & $\begin{array}{c}\text { Eksperimen } \\
\text { II }\end{array}$ & $-32.6667^{*}$ & 0,000 \\
\hline
\end{tabular}

From table 4 above, it can be concluded that there was a significant 
differences between groups. The difference can be seen in the mean difference column. The above-mentioned mean difference column showed evidence that there is an effect on increasing arm muscle power between the studied groups. This can be known from the mean diffrence value, that the experimental group II is more optimal in increasing arm muscle power compared to the experimental group I and the control group. The same thing also happened to leg muscle power, which showed that experiment group II is more optimal than experimental group I and control group. This is because the best value for leg muscle power is the greatest value (maximum).

The following summarizes the results of the post hoc test with LSD for the leg muscle power variables

\section{Table 5. Post-Hoc Test Results with LSD of leg Muscle Power Variable}

\begin{tabular}{|cc|c|c|}
\hline \multicolumn{2}{|c|}{ Kelompok } & Mean difference & Signifikansi (p) \\
\hline \multirow{2}{*}{$\begin{array}{c}\text { Eksperimen } \\
\text { I }\end{array}$} & $\begin{array}{c}\text { Eksperimen } \\
\text { II }\end{array}$ & $-27.0250^{*}$ &, 042 \\
\cline { 2 - 4 } & Kontrol & 24.0833 &, 068 \\
\hline \multirow{2}{*}{$\begin{array}{c}\text { Eksperimen } \\
\text { II }\end{array}$} & \begin{tabular}{c} 
Eksperimen I \\
\cline { 2 - 4 } Kontrol
\end{tabular} & 27.0250 &, 042 \\
\hline \multirow{2}{*}{\begin{tabular}{c} 
Kontrol \\
\cline { 2 - 4 }
\end{tabular}} & \begin{tabular}{c} 
Eksperimen I \\
\cline { 2 - 4 }
\end{tabular} & $51.1083^{*}$ &, 000 \\
\hline II & $51.1083^{*}$ &, 068 \\
\hline
\end{tabular}

From the table above can be concluded that there was a significant differences between groups. The difference can be seen in the mean difference column. The above-mentioned mean difference column showed evidence that there is an effect on the increase in leg muscle power between the studied groups. So from the results of different test of muscle power muscles and leg muscle power variables between groups can be concluded that the chess press and leg press exercisesprovide greater improvement than bench press and sitting calf exercises thatdelivered to the control group.

\section{DISCUSSION}

In the experimental group I obtained a significant increase in arm muscle power after being treated by bench press and siting calf, this is seen from the mean of arm muscle power when pretest namely 442. and at posttest that is 470.6. The difference between posttest and pretest arm muscle power mean was 28.3. If the increase in arm muscle power converted into percentage form then the percentage of arm muscle power increases by $6.0 \%$. In addition, the increase is also seen in leg muscle power, this can be seen from the mean of leg muscle power at pretest that is 994.9 while the mean of leg muscle power at posttest was 1046.0. The difference between the mean of posttest with pretest leg muscle power was 51.1. If the increase in arm muscle power is converted into percentage form then the 
percentage increase in leg muscle power by $4.9 \%$. Then t-test or pariad performed that showed that all test results show all significant dependent variables namely 0.000 that means less than 0.05 . Thus, it can be concluded that there was a difference after being given bench press and sitting calfexercises. That means there is an effect of bench press and sitting calf exercises to theimprovedarm muscle power and leg muscle power.

Obtained variable data results showed increased arm muscle power and leg muscle power was significant after being treated by Chest Press and Leg Press that can be seen from the mean of arm muscle power when pretest namely 457.6 and at posttest that is 503.5. The difference between posttest andpretest mean of arm muscle power was 45.9. If the increase in arm muscle power converted into percentage form then the percentage increase in arm muscle power is $9.1 \%$. In addition, the increase also occurs in leg muscle power, this can be seen from the mean of leg muscle power at pretest that is 969.3 while the mean of leg muscle power at posttest was 1047.4. The difference between the mean of posttest with pretest on leg muscle power was 78.2. If the increase in leg muscle power converted into percentage form then the percentage increase in leg muscle power by $7.5 \%$.

Based on the calculation of paried test there were differences before and after the treatment of each dependent variable namely arm muscle power and leg muscle power. The probability or significance level of each variable was 0.000 means $\mathrm{P}<0.05$. Thus, it can be concluded that there is a difference after being given a chest press and leg press training program. This means that there was an effect of chest press and leg press exercises against improvedarmmuscle power and leg muscle power.

To find out the difference of bench press and sitting calf exercises with chest press and leg press on arm muscle power and limb muscle power using MANOVA test and continued with LSD (Least Significant Difference) analysis technique. From the LSD test output showed that there was a difference in the effect of improvedarms muscle power and leg muscle power whereas the chest press and leg press exercises on group II more effectively increase the arms muscle power and leg muscle power. In line with the results of research Klaus (2012) which depicted that exercise using leg press machines more effective to improved jump performance in short term power training.

\section{CONCLUSION}

Based on the results of research and previous discussions, it will be described the following conclusions:

1. There is a significant effect of bench press and sitting calf exercises on increasing armmuscle power and leg muscle power.

2. There is a significant effect of chest press and leg press exercises on increasing armmuscle power of and leg muscle power. 
3. There is a difference in effectiveness between bench press and sitting calf exercises with chest press and leg press exercises for improving arm muscle and leg muscle power. As well as chest press and leg press exercises is more effective in improving arms muscle power the and leg muscle power.

\section{Suggestion}

Based on the results obtained after conducting research, some suggestions that can be submitted by researchers are:

1. To improvearms muscle power and leg muscle power in athlete especially in dynamic sports is not only done with conventional exercise, but can be done with intensive training method in the form of chest press and leg press exercise program.

2. Model of bench press and sitting calf training program or chest press and leg press training programs can be recommended and applied to the exercise program in order to increase the arms muscle power and legs muscle power of the athlete.

3. In drafting the exercise program should be based on individual principles so that every athlete who undergoes the exercise can develop well especially in group practice.

4. In choosing the type of exercise should considering to the muscles that contract on the desired type of exercise and based on the goal of the exercise to be achieved. In order for the exercise can really achieve the expected goal.

\section{REFRENCES}

ACSM (American College of Sport Medicine). (2012). Foundation of Strenght Training and Conditioning.USA: American College of Sport Medicine.

Agung, Anak Ngurah B. (2016).Pengaruh Latihan Bench Press dan Chest Press terhadap Kekuatan (strength) dan Power Otot Lengan pada atlet Shorinji Kempo.Tesis Magister. Universitas Negeri Surabaya.

Ambarukmi, Dwi Hatmisari. Dkk. (2007).Pelatihan Pelatih Fisik Level 1. Jakarta: Asisten Deputi Pengembangan Tenaga dan Pembinaan Olahraga Deputi Bidang Peningkatan Prestasi dan IPTEK Olahraga Kementerian Negara pemuda dan olahraga

Arief, Nur Ahmad. (2012). Pengaruh Latihan Power Lengan dan Kekuatan Otot Tungkai terhadap Ketepatan Pukulan Jumping Smash pada Mahasiswa UKM Bulutangkin Unesa. Tesis Magister. Universitas Negeri Surabaya.

Arikunto, Suharsimi. 2010. Prosedur Penelitian Suatu Pendekatan Praktik. Jakarta: PT. Rineka Cipta.

Asdep PTPK, Kemenegpora. (2007). Pelatihan Pelatih Fisik Level 1. Jakarta: Kemenegpora.

Asdep PTPK, Kemenegpora. (2008). Pedoman dan Materi Pelatihan Pelatih Tingkat Dasar. Jakarta: Kemenegpora.

Baechle, T. R.and Groves B. R.(2003). Latihan Beban.Jakarta: PT. Raja Gravindo Persada. 
Baechle, T. R., Earle, R. W. (2012). Fitness Weight Training. United States: Human Kinetics.

Barros, C, C,.Caldas, C, P,. (2016). Strength, Power and Resistance Training in Older Women. Journal Health, 2016, 8, 575-582

Beam, Wiliam. C. And Adam, Gine.M. (2011). Exercise physiology LaboratoryManual. New York: Mc. Graw Hill.

Bench Press (2015) http://www.bodybuilding,com diakses pada 23 desember 2016.

Bellar, David M. Muller, Matthew D. Barkley, Jacob E. Kim, Chul-Ho. Ida, Keisuke. Ryan, Edward J. Bliss, Mathew V. Glickman, Ellen L. (2011). The Effects of Combined Elastic- and Free-Weight Tension vs. FreeWeight Tension on One-Repetition Maximum Strength in the Bench Press.Journal of Strength \& Conditioning Research. Volume 25 - Issue 2 pp 459-463doi: 10.1519/JSC.0b013e3181c1f8b6

Bird, et al.(2005).The Designing Resistance TrainingProgrammes to Enhance Muscular Fitness. Sports Med 2005, 35 (10): 841-851.

Bompa, T. O.and Haff, G. G. (2015). Periodezation Theory and Methodology Of Training. United States. Human Kinetics.

Brown, L. E. (2007). Strengh Training: National Streng Andconditioning Asociation. United States. Human Kinetics.

Calhoon and Fry. (1999). Injury rates and profiles of elite competitive weightlifters.Journal of Athletic Training 1999;34(3):232-238.

Chusaini (2014).Pengaruh Pelatihan Hand Paddles Swim dan Parachute Swim terhadap Poer Otot Lengan dan Kecepatan Renang 50 Meter Gaya Bebas. Surabaya: Unesa.

Dale, M, J,. (2017). No Effect of a Whey Growth Factor Extract during Resistance Training onStrength, Body Composition, or Hypertrophic Gene Expression in ResistanceTrained Young Men. Journal of Sports Science and Medicine (2017) 16, 230-238

Delavier, F. (2005). Streng Training Anatomy. United States. Human Kinetics.

Glenn, L.(2007).Best Leg Exercise. California.

http://www.musclemagfitness.com/bodybuilding/exercises/best-leg-

exercises.htmldiunduh tanggal 01 januari 2017.

Harsono. (1988). Coaching dan Aspek-Aspek Sosiologis dalam Coaching. Jakarta: Depdikbud Dirjen Dikti PPLTK.

Hoffman, J.R. 2012.Science of Stregth and Conditioning Series NSCA's Guide to Program Design. United States: Human Kinetics.

Hoffman, AJ. (2014). Overload Control Centre Bypass Detection System. International Conference on Intelligent Transportation Systems (ITSC)https://content.pattersonmedical.co.uk/items/MediumSquare/55651

2.jpg. diakses unduh pada tanggal 28 Desember 2016.

http://thumbnail.image.rakuten.co.jp/@0_mall/sports-diary/cabinet/img_002/ybntkk5414.jpg.

http://thumbnail.image.rakuten.co.jp/@0_mall/sports-diary/cabinet/img_002/ybntkk5414.jpg.

Iskandar.Z. dkk.(1986).BukuI Panduan Tekhnis, tes \& Latihan KesegaranJasani Untuk anak Sekolah 16-17.

Janusevicius, D,. (2017). Effects of High Velocity Elastic Band versus Heavy Resistance Training on Hamstring Strength, Activation, and Sprint 
Running Performance.Journal of Sports Science and Medicine (2017) 16, 239-246

Kavanaugh. (2007). The effects of training design, individual characteristics and work environment on transfer of training. http://onlinelibrary.wiley.com/doi/10.1111/j.14682419.2007.00286.x/abstr act.

Klaus Wirth, Michael Keiner, Hagen Hartmann, Andre Sander, and Christoph Mickel. (2012). Effect Of 8 Weeks Of Free-Weight And Machine-Based Strength Training On Strength And Power Performance.Journal of Human Kinetics Volume 53/2016, 201-210 DOI: 10.1515/hukin2016-0023.

Kusnanik, Nining W., Nasution, Juanita., Hartono, Soetanto. (2011). Dasar-dasar fisiologi olahraga. Surabaya: Unesa University Press.

Kraemer, William J., Szivak, Tunde K. (2012). Strength Training For The Warfighter. Journal of Strength and Conditioning Research.26(7)/S107S118.

Larry, Kenney W., Jack, H. Wilmore, David L. Costill. (2012). Physiology Of Sport And Exercise. United States of America: Human kinetics.

Lubis, Johansyah. (2013). Panduan Praktis Penyusunan Program Latihan. Jakarta: Rajawali Press.

Maksum (2008). Metodologi Penelitian. Unesa University Press.

Maksum, Ali. (2012). Metodologi Penelitian dalam Olahraga.Surabaya: Unesa University Press.

Ni, Meng; Signorile, Joseph F. (2017).High-Speed Resistance Training Modifies Load-Velocity and Load-Power Relationships in Parkinson's Disease. Journal of Strength \& Conditioning Research: October 2017 - Volume 31.Issue 10. Page 2866-2875. Doi: 10.1519/JSC.0000000000001730

Hasanah, Mufidatul. (2013). Pengaruh Latihan Pliometrik Depth Jump dan Jump To Box Terhadap Power Otot Tungkai. FIK, Universitas Negeri Semarang.

Mylsidayu, Apta. 2014. Ilmu Kepelatihan. Bekasi: Percetakan ST.

Mylsidayu, Apta. Kurniawan, Febi. (2015). Ilmu Kepelatihan Dasar.Bandung: Alfabeta Bandung.

Nala, N (1998). Prinsip Pelatihan Fisik Olahraga. Denpasar. Program Pasca Sarjana Studi Fisiologi Olahraga Universitas Udayana Denpasar.

Olsen, Olav., Sjohaug, Mona., Beekvelt, Mireille Van., Mork, Paul Jarle.(2012). The Effect of Warm-Up and Cool-Down Exercise on Delayed Onset Muscle Soreness In the Quadriceps Muscle: A Randomized Controlled Trial. Journal of Human Kinetics vol. 35.

Pearce, Evelyn C. (2014). Anatomy and Physiology for Nurses. Jakarta: CV Prima Grafika.

Rafin, Muhammad. (2014). Pengaruh Pelatihan Leg Press dan Shoulder Press dengan Sitting Calf dan Chest Press terhadap Peningkatan Power Tungkai dan Power Lengan. Tesis tidak diterbitkan. Surabaya: Pascasarjana Unesa.

Riadi.M, (2007).Raih Kebugaran Jasmani melalui LatihanBeban (Weight Training). Mataram: Institut Keguruan Ilmu Pendidikan Mataram.

Riduwan (2008). Dasar-Dasar Statistika. Bandung: Alfabeta 
Sajoto.(1995). Peningkatan dan Pembinaan Kekuatan Kondisi Fisik Dalam Olahraga.Semarang Dahara Prize.

Schoenfeld, B, J, Contreras, B, Vigotsky, A, Peterson, M,. (2016). Differential Effects of Heavy versus Moderate Loads on Measures of Strengthand Hypertrophy in Resistance-Trained Men.Journal of Sports Science and Medicine (2016) 15, 715-722.

Shibata, Keisuke., Takizawa, Kazuki., Mizuno, Masao. (2015). Does Power Output Vary Accordingly With High Load Resistance Training? A Comparative

Study Between Bulk-Up and Strength-Up Resistance Training. Movement, Health \& Exercise, 4(2), 9-18, 2015.

Sugiyono. (2015). Metode Penelitian Kuantitatif Kualitatif dan R\&D. Bandung: Alfabeta.

Sugma, Lukmi Maulana. Setyo, Hadi Subiyono. (2015). Latihan Beban Lunge dan Squarter Squat untuk Meningkatkan Kecepatan Renang Gaya Dada.JSSF: 4 (3), hal 27-31.

Sukadiyanto., Muluk, Dangsina. (2011). Pengantar Teori dan Metodologi Melatih Fisik. CV. Bandung: Lubuk Agung.

Tangkudung, James. Wahyuningtyas.Puspitorini.(2012). Kepelatihan Olahraga "Pembinaan Prestasi Olahraga”.Jakarta : Cerdas Jaya.

UNESA, (2015) Pedoman Penulisan Tesis Dan Disertasi Program Pascasarjana. Surabaya: PPS Universitas Negeri Surabaya.

Usba, Muh. (2016). Pengaruh Latihan Wave Squat dan Double Leg Hop Progression dengan Leg Press dan Sitting Calf terhadap Peningkatan Kekuatan Otot Tungkai dan Power Tungkai. Surabaya: Pascasarjana Unesa.

Weider, J. (2015). Muscle and Fitness Training Notebook. Yogyakarta: Writing Revolution.

West, Daniel J. Cunningham, Daniel J. Crewther, Blair T. Cook, Christian J. Kilduff, Liam P. (2013) Influence of Ballistic Bench Press on Upper Body Power Output in Professional Rugby Players. Journal of Strength \& Conditioning Research: Volume 27 - Issue 8 - p 2282-2287. Doi: 10.1519/JSC.0b013e31827de6f1

Wiarto, Giri. (2015). Panduan Berolahraga Untuk Kesehatan dan Kebugaran. Yogyakarta: Graha Ilmu

Widiastuti.(2011). Tes dan Pengukuran Olahraga. Jakarta: PT. Bumi Jaya.

Zainudin, Wani Norma. (2014). Pengaruh Penelitian Shoulder Press, Leg Press dan Chest Press, Sitting Calf terhadap Power Lengan dan Power Tungkai. Tesis tidak diterbitkan. Surabaya: Pascasarjana Unesa. 